\title{
Readiness of Teachers and Students to Take Minimum Competency Assessments
}

\author{
Meni Handayani*, Novrian Satria Perdana, Ikhya Ukhlumudin \\ Researcher at Center of Policy Research, Agency Research and Development and Book \\ Ministry of Education and Culture \\ Jakarta, Indonesia \\ *meni_handayani@yahoo.com,novrian1711@gmail.com,ikhya.puslitjak@gmail.com
}

\begin{abstract}
This research aims to analyze the readiness of teachers and students through their perceptions of the Minimum Competency Assessment (AKM) questions. This research was conducted at the Junior High School and Senior High School levels, the samples took in Jakarta, Bogor, Depok, Tangerang and Bekasi. There are $60 \%$ of Junior High School teachers said that most of the AKM questions were in accordance with the learning method and process, but in this case, there are only $40 \%$ of high school teachers. Middle school students' perceptions of $54 \%$ and SMA 50\% said that the AKM questions were by the learning method or process. The learning process in schools has not emphasized students to think analytically. Teachers' readiness to face AKM needs to adjust teaching methods in the learning process. There are less than $50 \%$ of Junior High School and Senior High School teachers whose assessments were by the types of AKM questions. It means that more than $50 \%$ of the teachers do not use similar assessments with the AKM. There are $50 \%$ of Junior High School and Senior High School teachers said that most of the AKM was difficult. There are $28 \%$ of Junior High School and 34\% of Senior High School Students said that most of AKM is difficult. In working on AKM questions, students can obtain answers based on their opinions. For students, if they have answered, it will be worth it. A recommendation that the teacher's book: be revised with HOTS learning accompanied by examples of HOTs questions. Readability of questions, such as the use of words that are familiar to students, clarity of appearance of pictures and complexity of question discourse.
\end{abstract}

Keywords-teacher and student readiness, minimum competency assessment

\section{INTRODUCTION}

In Indonesia conducts minimum competency assessments and character surveys to map and enhance the quality of education nationally. The minimum competency assessment for the National Examination substitute measures reasonable competence that can be used to solve problems in various contexts, both personal and professional (work). Competency that will be measured, for example, are reasoning competencies about literacy and numeracy.

The minimum competency assessment for literacy and numeracy reflects the results of PISA, which have not increased from year to year. Literacy and numeracy skills associated with real life are important for students to master in order to hone their reasoning and logical skills.

One way of creating this global policy lexicon is to look at what is measured in PISA. PISA provides comparisons of the competencies of 15-year-olds that are relevant to everyday adult life, rather than simply evaluating curricula-based knowledge (OECD 2001). It is also said that assessments that test curriculum only offer a measure of internal efficiency and cannot reveal how schools prepare students for adult life (OECD 2001). As such, PISA can be seen as a platform for policy construction, mediation and diffusion at the national, international and even global levels (Rizvi and Lingard in Guorui Fan and Thomas S. Popkewitz [1]).

Minimum Competency Testing (MCT) is an attempt to establish minimal acceptable levels for educational attainment within subject areas such as science, mathematics, and reading. Seventeen of fifty states currently require high school students to pass a minimum competency test in order to graduate (Henkoff in Rodney D. Coates \& Karen R. Wilson-Sadberry [2]).

Why is it only focused on literacy and numeracy? Literacy and numeracy are general and basic competences. The ability to think about language and mathematics are required in various contexts, such as in personal, social, or professional. By measuring basic competencies (not curriculum or lesson content), the message to be conveyed is that teachers are expected to innovate in developing students competencies through various lessons by using student-centered teaching. It is also same as the article from Henry M. Brickell [3]: there are basic skills - such as reading, writing, and arithmetic used in both school and life, which is why we call them "basic". You could test competency in each: 1) Basic skill, 2) School subject, 3) Life area, 4) Basic skill applied in each school subject and 5) Basic skill applied in each life area.

The focus of the assessment is the competence of intellective, so that the measurement results do not merely reflect the academic achievement of Indonesian and Mathematics lessons. Literacy and numeracy should be 
developed through various subjects, including science, social studies, citizenship, religion, art, and so on. This message is necessary for teachers, schools, and students to minimize the risk of narrowing the curriculum in Indonesian and Mathematics lessons. In order to the assessment which is not usually carried out in Indonesia to run as expected, it is necessary to know the readiness of the school and what the school requires in facing the Minimum Competency Assessment (AKM).

This research aims to 1) analyze teacher and student perceptions of AKM questions (suitability of questions to the learning process, difficulty level, readability) and 2) analyze teacher and student perceptions about initiatives that will be carried out after the AKM policy (change in learning or teaching strategies).

\section{METHODS}

The survey method was carried out in South Jakarta, Bogor, Depok, Tangerang and Bekasi. There were 1,118 Junior High School students and 1,406 high school students, teacher respondents from Junior High School was 221 and Senior High School was 308 from participants of the AKM rehearsal in 2020. After ascertain the answers according to the survey, 60 teachers and 30 students were interviewed to find out the reasons and explanations for the answers to the survey result. This research provides input to the Center for Assessment and Learning, the Center for Curriculum and Books and the Ministry of Education and Culture in general in preparing the minimum competency assessment and anticipating obstacles that arise.

\section{RESULTS AND DISCUSSION}

The results of the research were divided into two parts, such as the perception of teachers and the students towards AKM questions, and the perception of teachers and students about the initiatives that will be carried out after the AKM policy.

\section{A. The Perceptions of Teachers and Students Towards AKM Questions}

Some of the things that will be explained are related to the perceptions of teachers and students on AKM questions including: the suitability of the AKM questions with the learning material, the suitability of the AKM questions with the learning method, the suitability of the AKM questions with the daily assessment questions, the difficulty level of the AKM questions, the legibility of the AKM questions, suitability of AKM questions with the socio-cultural context and actual conditions.

1) The suitability of the AKM questions with the learning material: The suitability of the AKM questions with Basic Competencies or learning materials, more than $50 \%$ of the teachers said that the AKM questions were inappropriate or a few were appropriate. On the other hand, more than $50 \%$ of students said that most or all of the AKM questions were appropriate. It can be shown in the following table 1 .

TABLE I. SUITABILITY OF AKM QUESTIONS WITH LEARNING MATERIALS

\begin{tabular}{|c|c|c|c|c|}
\hline $\begin{array}{l}\text { Conformity of } \\
\text { AKM questions } \\
\text { with basic } \\
\text { competency in } \\
\text { subjects }\end{array}$ & $\begin{array}{l}\text { Perceptions } \\
\text { of Junior } \\
\text { High Schoo } \\
\text { Teachers (n } \\
=221)\end{array}$ & $\begin{array}{c}\text { Perception } \\
\text { of Senior } \\
\text { High Schoo } \\
\text { Teachers } \\
(\mathbf{n}=\mathbf{3 0 8})\end{array}$ & $\begin{array}{l}\text { Perceptions } \\
\text { of Junior } \\
\text { High School } \\
\text { Teachers } \\
(n=1118)\end{array}$ & $\begin{array}{l}\text { Perceptions } \\
\text { of Senior } \\
\text { High School } \\
\text { Students } \\
(n=1406)\end{array}$ \\
\hline All appropriate & $6.3 \%$ & $3.2 \%$ & $11.8 \%$ & $6.7 \%$ \\
\hline $\begin{array}{l}\text { Mostly } \\
\text { appropriate }\end{array}$ & $37.6 \%$ & $18.5 \%$ & $40.3 \%$ & $44.3 \%$ \\
\hline $\begin{array}{l}\text { A small portion } \\
\text { is appropriate }\end{array}$ & $40.7 \%$ & $45.8 \%$ & $39.4 \%$ & $37.9 \%$ \\
\hline Inappropriate & $15.4 \%$ & $32.5 \%$ & $8.4 \%$ & $11.1 \%$ \\
\hline
\end{tabular}

The reason of the teacher said it was inappropriate because the teacher thought that most of the AKM questions were general questions, there were no questions that contained subjects. As for the teacher who said it was appropriate such as integrated Mathematics in numeracy questions, such as percentages, opportunities, and the ability to read Cartesian diagrams. The students' reasons for saying it was inappropriate were "The material in school was clear about the substance has been taught, and students knew the correct answers to the questions asked; meanwhile, the AKM questions require our own thoughts and need our own analysis to answer them." The students reason said it was appropriate because the material that came out on the AKM questions were appropriate with the explanation. It deals with discounts and percentages are in the material for grades 7, 8 and 9. Students were a little bit out of the way, but after reading it again, students can comprehend the problem. For Indonesian there are slogans, facts and evidence.

2) The suitability of the AKM questions with the learning method: The majority of Junior High School teachers said that the AKM questions were appropriate with the learning method, but the majority of Senior High School students said the opposite statement. Almost the same as the students, approximately $50 \%$ said it was appropriate. It can be seen in the following table 2 .

TABLE II. THE SUITABILITY OF THE AKM QUESTIONS WITH THE LEARNING METHOD

\begin{tabular}{|l|l|l|l|l|}
\hline $\begin{array}{c}\text { The suitability } \\
\text { of the AKM } \\
\text { questions with } \\
\text { the learning } \\
\text { method }\end{array}$ & $\begin{array}{c}\text { Perceptions } \\
\text { of Junior } \\
\text { High } \\
\text { School } \\
\text { Teachers } \\
(\mathbf{n = 2 2 1})\end{array}$ & $\begin{array}{c}\text { Perceptions } \\
\text { of Senior } \\
\text { High } \\
\text { School } \\
\text { Teachers } \\
(\mathbf{n = 3 0 8 )}\end{array}$ & $\begin{array}{c}\text { Perceptions } \\
\text { of Junior } \\
\text { High } \\
\text { School } \\
\text { Students } \\
(\mathbf{n = 1 1 1 8})\end{array}$ & $\begin{array}{c}\text { Perceptio } \\
\text { ns of } \\
\text { Senior } \\
\text { High } \\
\text { School } \\
\text { Students } \\
\text { (n=1406) }\end{array}$ \\
\hline $\begin{array}{l}\text { Entirely } \\
\text { appropriate }\end{array}$ & $6.8 \%$ & $5.2 \%$ & $12.0 \%$ & $7.0 \%$ \\
\hline $\begin{array}{l}\text { Mostly } \\
\text { appropriate }\end{array}$ & $52.5 \%$ & $34.7 \%$ & $42.0 \%$ & $43.2 \%$ \\
\hline $\begin{array}{l}\text { A fraction is } \\
\text { appropriate }\end{array}$ & $35.3 \%$ & $44.5 \%$ & $34.7 \%$ & $38.8 \%$ \\
\hline Inapropriate & $5.4 \%$ & $15.6 \%$ & $11.3 \%$ & $10.9 \%$ \\
\hline
\end{tabular}


The reason of the teachers said that the AKM questions were inappropriate with the learning method was because the teacher thought that the learning process in schools had not emphasized students to think analytically related to the material taught by the teachers. Students are given more subject matters to remember and understand. As for those who say it is appropriate, it stands to reason that in learning students are required to think analytically. In addition, in learning process the teacher assigns students to search for text from printed media related to the latest news. The learning method uses pictures, then the teachers asked to tell the content of the video (Indonesian teacher)

Based on research from the Research and Development Center for Research and Development of the Ministry of Education and Culture: (i) Most of teachers and also school principals have not mastered yet about the concept of learning with HOTs. The implementation of HOTs learning has been indicated in the syllabus and lesson plans, however the planning has not been shown in the learning process in the classroom. In addition to schools that have not implemented HOTs learning, there are also certain schools that have implemented HOTs learning. According to Erna Yayuk, Tyas Deviana, Nawang Sulistyani's [4] research, teachers are skilled in designing HOTS-based planning and learning. This is evidenced by the indicator that in the preparation of the lesson plan the operational words used already refer to the cognitive levels $\mathrm{C}-4$ to $\mathrm{C}-6$. The teacher plans by selecting a learning model, namely PBL. The learning steps developed also invite children to think at a higher level, work scientifically by following the planned learning syntax. Teachers are skilled in selecting, utilizing and developing methods, models, media, learning resources that support HOTS-based learning objectives.

3) The suitability of the AKM questions with the daily assessment questions: There are more than $50 \%$ of the teachers said the AKM questions were inappropriate or a small part was appropriate with the daily assessment questions given by the teacher. the other hand, about $50 \%$ of students said most or all of the AKM questions were appropriate with the daily assessment questions. It can be shown in the following table 3 .

TABLE III. SUITABILITY OF THE AKM QUESTIONS WITH THE DAILY ASSESSMENT QUESTIONS

\begin{tabular}{|l|l|l|l|l|}
\hline $\begin{array}{c}\text { The } \\
\text { suitability of } \\
\text { the AKM } \\
\text { questions with } \\
\text { the learning } \\
\text { method }\end{array}$ & $\begin{array}{c}\text { Perceptions } \\
\text { of Junior } \\
\text { High } \\
\text { School } \\
\text { Teachers } \\
\text { (n=221) }\end{array}$ & $\begin{array}{c}\text { Perceptions } \\
\text { of Senior } \\
\text { High } \\
\text { School } \\
\text { Teachers } \\
\text { (n=308) }\end{array}$ & $\begin{array}{c}\text { Perceptions } \\
\text { of Junior } \\
\text { High } \\
\text { School } \\
\text { Students } \\
\text { (n=1118) }\end{array}$ & $\begin{array}{c}\text { Perceptions } \\
\text { of Senior } \\
\text { High } \\
\text { School } \\
\text { Students } \\
\text { (n=1406) }\end{array}$ \\
\hline $\begin{array}{l}\text { Entirely } \\
\text { appropriate }\end{array}$ & $2.3 \%$ & $3.6 \%$ & $9.9 \%$ & $7.4 \%$ \\
\hline $\begin{array}{l}\text { Mostly } \\
\text { appropriate }\end{array}$ & $40.7 \%$ & $26.0 \%$ & $39.4 \%$ & $45.8 \%$ \\
\hline $\begin{array}{l}\text { A fraction is } \\
\text { appropriate }\end{array}$ & $34.4 \%$ & $42.9 \%$ & $38.8 \%$ & $35.8 \%$ \\
\hline Inappropriate & $22.6 \%$ & $27.6 \%$ & $11.9 \%$ & $11.0 \%$ \\
\hline
\end{tabular}

The teacher's reason for saying that the AKM questions were inappropriate with the daily assessment was because the teacher developed the questions by referring to Basic Competencies (KD), and the teachers rarely make questions that required students to think at high levels (HOTs). In this regard, Juhanda's [5] research found that the average percentage of the emergence of questions that develop highlevel skills (Higher-Order Thinking Skills) ranging from questions C4 (analyzing) to C6 (creating) has a low average percentage. Therefore, the emergence of the Revised Bloom Cognitive level questions in BSE, especially those that develop Higher-Order Thinking Skills, still needs to be improved. Enhancing the ability of teachers in developing HOTs based questions has been done. In the research of Hanik, Umi, Isna Ida Mardiyana and Abdul Rosid [6], it was found that community service activities that aim to improve teacher competence in integrating HOTS in learning have been achieved by increasing the knowledge and understanding of participants which is marked by the success of the participants in compiling HOTS-based questions for several subject contents such as 1) mathematics, 2) natural sciences, and 3) social sciences by $71 \%$. In addition, the teacher's response was relatively good, which was evident from the activeness of the participants in asking, answering questions and the practice of preparing HOTS-based questions. This situation is due to the level of needs or interests of teachers related to the need to have the competence to implement the curriculum of 2013 by integrating several elements, one of them is HOTS

Some of teachers said there were questions that appropriate with the AKM questions, although there are not many, there were questions related to literacy, for example the material that determines or analyzes information in the text, (Indonesian language teacher). The student's reason for saying that the AKM questions were inappropriate to the daily assessment was because the teacher had never given questions as in the AKM, the teacher emphasized more on the main content of learning material and had never given such a question. Students who said the teacher's assessment in the classroom was appropriate with the AKM questions, the reason was "For literacy questions, I quite often do it in class; but for the questions in the form of tables I rarely find them, especially questions from school. The problem types and models are different. I usually do the type of questions such as AKM in "tutoring for UTBK preparation."

4) Difficulty level of AKM questions: In general, teachers do not find the difficulty in AKM questions. However, the proportion of students who admitted that they did not have problems or difficulties with AKM questions was even greater. It can be shown in the following table 4 . 
TABLE IV. DIFFICULTY LEVEL OF AKM QUESTIONS

\begin{tabular}{|l|l|l|l|l|}
\hline $\begin{array}{c}\text { The } \\
\text { suitability of } \\
\text { the AKM } \\
\text { questions } \\
\text { with the } \\
\text { learning } \\
\text { method }\end{array}$ & $\begin{array}{c}\text { Perceptions } \\
\text { of Junior } \\
\text { High School } \\
\text { Teachers } \\
\text { (n=221) }\end{array}$ & $\begin{array}{c}\text { Perceptions } \\
\text { of Senior } \\
\text { High School } \\
\text { Teachers } \\
(\mathbf{n = 3 0 8 )}\end{array}$ & $\begin{array}{c}\text { Perceptions } \\
\text { of Junior } \\
\text { High School } \\
\text { Students } \\
(\mathbf{n = 1 1 1 8})\end{array}$ & $\begin{array}{c}\text { Perceptions } \\
\text { of Senior } \\
\text { High School } \\
\text { Students } \\
(\mathbf{n = 1 4 0 6 )}\end{array}$ \\
\hline $\begin{array}{l}\text { Entirely } \\
\text { appropriate }\end{array}$ & $2.7 \%$ & $2.6 \%$ & $3.0 \%$ & $2.8 \%$ \\
\hline $\begin{array}{l}\text { Mostly } \\
\text { appropriate }\end{array}$ & $45.7 \%$ & $47.1 \%$ & $25.6 \%$ & $30.6 \%$ \\
\hline $\begin{array}{l}\text { A fraction is } \\
\text { appropriate }\end{array}$ & $43.0 \%$ & $44.8 \%$ & $57.6 \%$ & $55.3 \%$ \\
\hline Inappropriate & $8.6 \%$ & $5.5 \%$ & $13.9 \%$ & $11.3 \%$ \\
\hline
\end{tabular}

The teachers reasons states that AKM questions are mostly difficult for students that can be distinguished based on two things, for instance difficulties in understanding and interpreting the questions, and difficulties in finding solutions to answer questions because AKM questions do not suitable with the material that students learn in class. The teacher said that the AKM questions were easy because in working on the questions that were important to be diligent and careful in reading, the answers were already in the discourse. If basic literacy and numeracy skills are often trained on students, they will be familiar with the form of AKM questions. Meanwhile, the reason students said that it was difficult because they had to be able to conclude the content of the reading. For example, in a question there are two texts which students are asked to compare. By examining the information from the two texts we must draw conclusions. Students felt confused which answer is right and wrong, because students think for themselves to give an opinion. As for students who answered easily the reason was because to answer questions referred to the information provided by the questions and we just needed to find information that was in accordance with the questions given.

5) The level of legibility of AKM questions: In general, the AKM questions tend to be understood by both teachers and students. However, there are also quite a lot of students who have not been able to understand AKM questions, especially for Vocational High School students. It can be seen on table 5.

TABLE V. READABILITY LEVEL OF AKM QUESTIONS

\begin{tabular}{|l|l|l|l|l|}
\hline $\begin{array}{c}\text { The level of } \\
\text { legibility of } \\
\text { AKM } \\
\text { questions }\end{array}$ & $\begin{array}{c}\text { Perceptions } \\
\text { of Junior } \\
\text { High } \\
\text { School } \\
\text { Teachers } \\
\text { (n=221) }\end{array}$ & $\begin{array}{c}\text { Perceptions } \\
\text { of Senior } \\
\text { High } \\
\text { School } \\
\text { Teachers } \\
\text { (n=308) }\end{array}$ & $\begin{array}{c}\text { Perceptions } \\
\text { of Junior } \\
\text { High } \\
\text { School } \\
\text { Students } \\
\text { (n=1118) }\end{array}$ & $\begin{array}{c}\text { Perceptions } \\
\text { of Senior } \\
\text { High } \\
\text { School } \\
\text { Students } \\
\text { (n=1406) }\end{array}$ \\
\hline $\begin{array}{l}\text { Entirely } \\
\text { appropriate }\end{array}$ & $21.3 \%$ & $18.9 \%$ & $18.4 \%$ & $19.4 \%$ \\
\hline $\begin{array}{l}\text { Mostly } \\
\text { appropriate }\end{array}$ & $59.7 \%$ & $54.6 \%$ & $45.9 \%$ & $49.7 \%$ \\
\hline $\begin{array}{l}\text { A fraction is } \\
\text { appropriate }\end{array}$ & $17.2 \%$ & $22.7 \%$ & $32.4 \%$ & $28.2 \%$ \\
\hline Inappropiate & $1.8 \%$ & $3.8 \%$ & $3.3 \%$ & $2.7 \%$ \\
\hline
\end{tabular}

The teachers reason thought the AKM questions had readability was difficult to be understood because they needed analysis. "The AKM issue is not easy to understand. Problems must be understood in advance, analogy, and analyzed. There are foreign terms in the question narrative, such as the term of aerostate." I have known the term and there is no explanation of the term in the question text." As for some teachers who said it was easy to be understood only because it was long and the text was compared to the text that had been missed, not juxtaposed. There was the reason for the students who said it was difficult to read, saying "In terms of readability of the questions, a small part of the AKM questions can be understood. Some of the AKM vocabulary questions were difficult to digest and difficult to understand, so one had to conclude the meaning of those questions. Meanwhile, those who say it is easy to understand say that there are no difficult questions because the answer refers to the information provided by the questions and we just have to look for information in accordance with the questions given. Easy to be understood, but something confusing. The population problem in 2013 is high in text but low in the diagram. There are differences between questions and pictures the numbers.

6) The suitability of the AKM questions with the sociocultural context and actual conditions: In general, the teacher considered the AKM questions according to the socio-cultural context and actual conditions. However, there are quite a lot of students who think that many AKM questions do not fit the context, especially vocational students $(40 \%)$. It can be seen on table 6 .

TABLE VI. SUITABILITY OF AKM Questions With The SocioCUltural CONTEXT AND ACTUAL CONDITIONS

\begin{tabular}{|l|l|l|l|l|}
\hline $\begin{array}{c}\text { The } \\
\text { legibility } \\
\text { level of } \\
\text { AKM } \\
\text { Questions }\end{array}$ & $\begin{array}{c}\text { Perceptions } \\
\text { of Junior } \\
\text { High } \\
\text { School } \\
\text { Teachers } \\
(\mathbf{n = 2 2 1})\end{array}$ & $\begin{array}{c}\text { Perceptions } \\
\text { of Senior } \\
\text { High } \\
\text { School } \\
\text { Teachers } \\
\text { (n=308) }\end{array}$ & $\begin{array}{c}\text { Perceptions } \\
\text { of Junior } \\
\text { High } \\
\text { School } \\
\text { Students } \\
(\mathbf{n = 1 1 1 8})\end{array}$ & $\begin{array}{c}\text { Perceptions } \\
\text { of Senior } \\
\text { High } \\
\text { School } \\
\text { Students } \\
(\mathbf{n = 1 4 0 6 )}\end{array}$ \\
\hline $\begin{array}{l}\text { Entirely } \\
\text { appropriate }\end{array}$ & $25.3 \%$ & $26.0 \%$ & $23.0 \%$ & $18.9 \%$ \\
\hline $\begin{array}{l}\text { Mostly } \\
\text { appropriate }\end{array}$ & $64.3 \%$ & $57.8 \%$ & $44.3 \%$ & $54.6 \%$ \\
\hline $\begin{array}{l}\text { A fraction is } \\
\text { appropriate }\end{array}$ & $8.6 \%$ & $14.3 \%$ & $27.1 \%$ & $22.7 \%$ \\
\hline Inappropiate & $1.8 \%$ & $1.9 \%$ & $5.6 \%$ & $3.8 \%$ \\
\hline
\end{tabular}

The teachers reason for saying that the AKM questions were inappropriate with the socio-cultural context and actual conditions was because "the content of the text was not related to the contextual problems needed by society in general". The question of discount is in accordance with life in the city, but not necessarily in the village '. anyone said that it is appropriate because "The problem is in accordance with today's life, for example regarding the line. The student's reason for saying it was not appropriate was because it did not represent the region, "About eating fish in Indonesia, in Bogor because it is far from the sea, rarely eats fish, it is cheaper to eat chicken. The problem is that it is not suitable for mountainous areas. For the 
present, such as using the internet is suitable. Meanwhile, those who say it is appropriate because it is in harmony with the environment, "In accordance with the surrounding environment, I often experience it myself. Regarding plastics, the environment has reduced plastic. In the city of Bogor in Indomaret, plastic is not given, if you want to use plastic you have to buy it."

The test can also lead to a cultural bias to a more extent, such as in the writing of Marry G. Commander (1980). Cultural bias may be one reason that a disproportionate number of minority students have failed the competency tests. The problem of standardized test use was recognized in Hobson. Judge Wright stated that the tests are "essentially a test of the student's command of standard English and grammar."109 Minority students may have had little opportunity to develop the necessary verbal skills to complete successfully such a test. Many minority students live in an environment where books are not readily available and where communication is often in the form of "black English." They also may not have been able to travel beyond their immediate neighborhoods, and thus their exposure to situations which might appear on the tests is limited. 110 It is recognized therefore that tests given to minority students are often "less precise and less accurate - so much so that test scores become practically meaningless .... [I]t is virtually impossible to tell whether the test score reflects lack of ability or lack of opportunity."

National tests conducted in Indonesia require to pay attention to the different cultural and environmental contexts in each region of Indonesia. For example, "trains" may not exist in all regions in Indonesia. So that the use of words should be adjusted to the circumstances of the area where the test is held or use common things, which all students know. The problem of different capacities and facilities in each region of Indonesia is also a problem but efforts are still being made to address it simultaneously with ongoing tests.

\section{B. Teachers and Students' Perceptions of Preparation for Facing AKM}

Several things will be explained related to the perceptions of teachers and students about preparation for AKM, namely the preparation of students, teachers, and schools in facing the AKM assessment. It can be seen on table 7 .

TABLE VII. TEACHER PREPARATION FOR THE AKM ASSESSMENT

\begin{tabular}{|l|l|l|}
\hline $\begin{array}{c}\text { The preparation } \\
\text { of teachers for } \\
\text { AKM assesment }\end{array}$ & $\begin{array}{c}\text { Perceptions of } \\
\text { Junior High } \\
\text { School Teachers } \\
(\mathbf{n = 2 2 1})\end{array}$ & $\begin{array}{c}\text { Perceptions of } \\
\text { Senior High } \\
\text { School Teachers } \\
(\mathbf{n = 3 0 8})\end{array}$ \\
\hline $\begin{array}{l}\text { Adjust the } \\
\text { allocation of } \\
\text { learning time the }\end{array}$ & $91 \%$ & $85 \%$ \\
\hline $\begin{array}{l}\text { convert } \\
\text { learning method }\end{array}$ & $87 \%$ & $84 \%$ \\
\hline $\begin{array}{l}\text { Changed the way } \\
\text { of scoring }\end{array}$ & $83 \%$ & $78 \%$ \\
\hline
\end{tabular}

Note: the respondent can answer more than one
Some of the teacher's statements regarding preparation for the AKM, including: (i) In order to students in expressing their opinions or stating ideas, the teacher will change their teaching methods by means of discussion. "I will change the teaching method, namely adjusting what students have to understand and what must be achieved in the AKM," (ii) Planning to change teaching methods, can encourage students' reasoning power. Students are trained to understand case studies according to teaching material. (iii) Prepare carefully before the implementation by giving questions that are in accordance with the AKM, learning the form of AKM questions, and providing modules for practicing AKM questions. Providing material based on the curriculum by teaching analytical, creative and directed thinking. (iii) Carry out a daily learning process and assessment according to HOTS orientation. Adjusting subjects to the demands of the AKM, namely changing teaching strategies and methods, teaching materials, assignments, and assessments in order to meet student competencies to solve AKM questions.

1) Preparation of students for the AKM assessment: Most of the students (about 70\%) admit that they will change their way of learning to prepare themselves for AKM. It can be shown in the following table 8 .

TABLE VIII. LEARNING METHODS IN FACING AKM

\begin{tabular}{|l|l|l|}
\hline $\begin{array}{c}\text { Learning techique } \\
\text { for AKM }\end{array}$ & $\begin{array}{c}\text { Perceptions of } \\
\text { Junior High } \\
\text { School students } \\
(\mathbf{n = 2 2 1})\end{array}$ & $\begin{array}{c}\text { Perceptions of Senior } \\
\text { High School students } \\
(\mathbf{n = 3 0 8})\end{array}$ \\
\hline Unchanged & $24 \%$ & $29 \%$ \\
\hline Changed partially & $65 \%$ & $62 \%$ \\
\hline Changed totally & $11 \%$ & $9 \%$ \\
\hline
\end{tabular}

There were students' answers that completely changed and some of them did not change in the way of learning. The reason students desire to convert is "Change completely, change my mindset to use reason and logic again, develop with friends, read more". "Change completely, read a lot, read and comprehend quickly". Students who do not change have the excuse because their learning has been in accordance with the AKM. "There is no need to change because the basic concept already understands just to use reason and logic."It doesn't change, because I am comfortable with the way I study now." In Chandra Muller's [7] research, It may be a much more complex problem to raise the levels of mathematics achievement among low-performing students who are about to graduate from Senior High School.

2) School readiness to face AKM: Most of the teachers admitted that their school was ready to face AKM. However, there were also quite a number of teachers who admitted that their schools were lacking and even unprepared for AKM, especially at the high school level $(35 \%)$. It can be seen on table 9 . 
TABLE IX. SCHOOL READINESS TO FACE AKM

\begin{tabular}{|l|l|l|}
\hline $\begin{array}{c}\text { Technique } \\
\text { how to deal } \\
\text { with AKM }\end{array}$ & $\begin{array}{c}\text { Perceptions of } \\
\text { Junior High } \\
\text { School } \\
\text { Teachers } \\
(\mathbf{n = 2 2 1})\end{array}$ & $\begin{array}{c}\text { Perceptions of } \\
\text { Senior High } \\
\text { School } \\
\text { Teachers } \\
(\mathbf{n = 3 0 8})\end{array}$ \\
\hline Ready & $77.4 \%$ & $65.3 \%$ \\
\hline Less ready & $16.3 \%$ & $30.2 \%$ \\
\hline Not ready & $6.3 \%$ & $4.5 \%$ \\
\hline
\end{tabular}

The teacher said the school was ready with reason because the school had implemented the 2013 Curriculum which was in line with the AKM issue. Others said that, "Ready to face AKM in 2021 provided that they receive guidance to set strategies and manage learning in accordance with AKM, especially in terms of assessment. Also, hope that there will be teacher training to make AKM questions ". There are also teachers who say the school is not ready because "There are students who have the ability to think according to the expected standards, but quite a lot of students who lack standard AKM intelligence seem more suitable for students who have high cognitive abilities, even though in this school children's intelligence is very high, variative". "Not ready, each teacher needs more understanding to make and compile AKM form questions and train them to students. Teachers do not understand the meaning and purpose of AKM. If it has to be implemented, teachers need to socialize the objectives and process of the AKM ". In addition, it is necessary to do the following: 1) Principals coordinate subject teachers related to improving student literacy and numeracy competencies to develop integrated teaching materials and compile contextual thematic assessment questions. 2) The teacher makes learning innovations (teaching methods, methods of assessment, and ways of assigning students) which are in line with the form of AKM assessment.

\section{CONCLUSION}

The following are the conclusions of this research which are described into three parts based on the objectives of this research.

- There is a perception that AKM questions are only relevant to Mathematics and Indonesian subjects. This is mainly because learning and assessment that emphasizes HOTS-based analytical skills, which are the AKM framework, have not been widely adopted in daily learning practices. There are perceptions that tend to differ between teachers and students regarding AKM questions, including the level of difficulty of the questions. Teachers tend to see AKM questions as difficult, while students tend to see the opposite. However, in terms of legibility of the AKM questions, the proportion of students who did not understand part or all of the AKM questions was quite large (around $30 \%$ ). This shows that many students find AKM easy, even though they basically don't understand the problem. Some of the constraints include new terms, long and complex questions, and questions that are not relevant to the regional context.

- In general, teachers admit that schools are ready to face AKM in 2021. However, quite a number of them admit that they are not ready, especially at the SMA and SMK levels $(35 \%)$. Some who were not ready admitted that they did not understand the objectives of AKM and needed training in making AKM questions. Both teachers and students have planned various changes in learning to prepare themselves for AKM. These changes concern teaching and learning methods, time allocation, and ways of assessing.

\section{RECOMMENDATION}

The following are policy recommendations based on the results and conclusions of this research.

- The Ministry of Education and Culture needs to anticipate the impact of the narrowing of the curriculum by teachers where learning will only focus on the "certain subjects" tested in the AKM - by integrating the context of other subjects (apart from Indonesian and Mathematics) in AKM questions and strengthening teachers' understanding of literacy and numeracy and supervisors through assistance by LPMP.

- BSNP and Pusmenjar in developing AKM questions should pay attention to the following: (i) The relationship between AKM questions and Basic Competencies (KD) for each subject in the 2013 Curriculum; (ii) Cognitive level HOTS level items developed based on basic competency or subject matter (related to literacy and numeracy); (iii) Variety of question types (multiple answers, essays, multiple choice, etc.) with contextual thematic problem forms; (iv) Readability of the questions, such as: the use of sentences or vocabulary or terms that are familiar to students, the clarity of the appearance of pictures or tables or diagrams, and the complexity of the question discourse.

- Pusmenjar, Puskurbuk, and DG GTK provide more intensive socialization regarding AKM policies and provide training to teachers in carrying out learning and assessments that are in line with the types of AKM questions.

\section{ACKNOWLEDGMENT}

This research was supported by the Centre for Education and Culture Research, Research and Development Agency, Ministry of Education and Culture and colleagues who helped. 


\section{REFERENCES}

[1] G. Fan and T.S. Popkewitz, Hand Book of Education Policy Studies, School/University, Curriculum, and Assessment, volume 2. Singapore: Springer Nature Singapore Pte Ltd.. 2020.

[2] R.D. Coates and K.R. Wilson-Sadberry, "Minimum Competency Testing: Assessing the Effects of Assessment," Sociological Focus, vol 27, no. 2, pp. 173-185, 1994.

[3] H.M. Brickell, "Seven Key Notes on Minimal Competency Testing" in Educational Leadership. Association for Supervision and Curriculum Development 1978

[4] E. Yayuk, T. Deviana, and N. Sulistyani, "Kemampuan Guru Dalam Implementasi Pembelajaran Dan Penilaian Hots Pada Siswa Kelas 4
Sekolah Indonesia Bangkok Thailand," JINoP (Jurnal Inovasi Pembelajaran), vol. 5, no. 2, pp. 107-122, 2019.

[5] Juhanda, "Analisis Soal Jenjang Kognitif Taksonomi Bloom Revisi pada Buku Sekolah Elektronik Biologi SMA,” Jurnal Pengajaran MIPA, vol. 21, no. 1, pp. 61-66, 2016.

[6] H. Umi, I.I. Mardiyana, and A. Rosid, "Peningkatan Kompetensi Guru dalam Mengintegrasikan HOTS (Higher Order Thinking Skills) Pada Pembelajaran,” Jurnal Pangabdhi, vol. 6, no. 1, pp. 44 - 48, 2020.

[7] C. Muller, "The Minimum Competency Exam Requirement, Teachers' and Students' Expectations and Academic Performance" in Social Psychology of Education. Kluwer Academic Publishers. Printed in the Netherlands, 1998. 